The research program of the Center for Economic Studies (CES) produces a wide range of theoretical and empirical economic analyses that serve to improve the statistical programs of the U.S. Bureau of the Census. Many of these analyses take the form of CES research papers. The papers are intended to make the results of CES research available to economists and other interested parties in order to encourage discussion and obtain suggestions for revision before publication. The papers are unofficial and have not undergone the review accorded official Census Bureau publications. The opinions and conclusions expressed in the papers are those of the authors and do not necessarily represent those of the U.S. Bureau of the Census. Republication in whole or part must be cleared with the authors.

\title{
Evidence on the Employer Size-Wage Premium From Worker-Establishment Matched Data
}

\author{
By \\ Kenneth R. Troske \\ Center for Economic Studies \\ CES 94-10 August 1994
}

All papers are screened to ensure that they do not disclose confidential information. Persons who wish to obtain a copy of the paper, submit comments about the paper, or obtain general information about the series should contact Sang V. Nguyen, Editor, Discussion Papers, Center for Economic Studies, Room 1587, FB 3, U.S. Bureau of the Census, Washington, DC 20233-6300, (301-763-2065) or INTERNET address snguyen@info.census.gov. 


\begin{abstract}
In spite of the large and growing importance of the employer size-wage premium, previous attempts to account for this phenomenon using observable worker or employer characteristics have met with limited success. The primary reason for this lack of success has been the lack of suitable data. While most theoretical explanations for the size-wage premium are based on the matching of employer and employee characteristics, previous empirical work has relied on either worker surveys with little information about a worker's employer, or establishment surveys with little information about workers. In contrast, this study uses the newly created Worker-Establishment Characteristic Database, which contains linked employer-employee data for a large sample of manufacturing workers and establishments, to examine the employer size-wage premium. The main results are: 1) Examining the cross-plant distribution of the skill of workers shows that managers with larger observable measures of skill work in large plants and firms with production workers with larger observable measures of skill.

2) Results from reduced form wage regressions show that including measures of the amount or type of capital in a worker's plant eliminates the establishment size-wage premium. 3) These results are robust to efforts at correcting for possible bias in the parameter estimates due to sample selection. While these findings are consistent with neoclassical explanations for the size-wage premium that hypothesize that large employers employ more skilled workers, their primary importance is that they show that the employer size-wage premium can be accounted for with employer-employee matched data. As such, these data lend support to models which emphasize the role of employer-employee matching in accounting for both cross-sectional and dynamic aspects of the wage distribution.
\end{abstract}

Keywords: Establishment Size, Wage Premium, Matched Data

I have benefited from helpful comments on an earlier version of this paper by Dan Black, David Card, Steve Davis, Mark Doms, Hank Farber, John Haltiwanger, Dan Hamermesh, Todd Idson, Ron Jarmin, Francis Kramarz, Alan Krueger, Walter Oi, Ariel Pakes, Mark Roberts, Bob Topel, and seminar participants at the Center for Economic Studies and Princeton University. Special thanks go to Will Carrington, Tim Dunne, and Brad Jensen for help throughout this project. All errors are mine. 


\section{Introduction}

The fact that large employers pay higher wages than small employers has long been recognized as an important component of the variation in worker wages. This phenomenon was first documented by Moore (1911) and later confirmed by King (1923), Mellow (1982), Oi (1983), and Brown and Medoff (1989) among others. Brown, Medoff and Hamilton (1990) show that the employer size-wage premium is approximately as large as the gender wage gap, and is larger than the wage differential associated with race and union status. Davis and Haltiwanger (1991) show that the real hourly wage gap between production workers in plants with 20 to 49 employees and production workers in plants with more than 5000 employees rose by $\$ 2.78$ between 1963 and 1986, while the gap for nonproduction workers rose by $\$ 1.53$ over this same period. Davis and Haltiwanger also show that this rise in the size-wage premium accounts for over one-half of the overall increase in wage inequality among U.S. manufacturing production workers between 1975 and 1986.

In spite of the large and growing importance of the size-wage premium, previous attempts to account for this premium in terms of observable worker or employer characteristics have meet with limited success. ${ }^{1}$ For example, Brown and Medoff (1989), using Current Population Survey (CPS) data, find that there remains a large and significant size-wage premium even after controlling for workers' age, sex, race, marital status, and union status. Davis and Haltiwanger (1991), using data from the Longitudinal Research Database (LRD), are unable to fully account for the size-wage premium even after controlling for plant age, energy cost, product specialization, and four-digit industry. The reason for this lack of success seems to be the lack of suitable data. While most theoretical explanations for the size-wage premium stress the matching of employers and workers as the driving force behind this phenomenon (e.g., Oi 1983, 1991; Hamermesh 1980, 1993; Dunne and Schmitz 1992), previous empirical work has relied on either worker surveys with little information about the characteristics of a worker's employer, or establishment surveys with little information about the characteristics of workers in the plant.

\footnotetext{
${ }^{1}$ The existence of the size-wage premium is a puzzle for labor economists because empirical evidence shows that jobs with small employers are of much shorter duration than jobs with large employers due to the higher failure rate and greater turnover of employment of small employers (Brown, Hamilton, and Medoff 1990; Davis, Haltiwanger and Schuh 1993; Troske 1992). Given this, the theory of equalizing differences says that workers in small firms and establishments should receivehigher wages to compensate them for the increased risk of unemployment (Rosen 1986).
} 
In contrast this paper uses the newly created Worker-Establishment Characteristic Database (WECD), which links data for manufacturing workers with data for their employers, to examine the employer size-wage premium. These linked employer-employee data allow me to examine a number of issues related to this phenomenon that previously were impossible to address. First, I can directly examine cross-plant differences in the observable skill of workers. Most neoclassical explanations for the size-wage premium claim that large plants are large because they are run by more skilled managers who in turn hire more skilled workers (Lucas 1979; Oi 1983, 1991; Hamermesh 1980, 1993; Dunne and Schmitz 1992). In this view employer size is related to a worker's wage because it is correlated with the unobserved ability of the worker. If these models are correct, then there should be a positive crossplant correlation between the skill of managers, the skill of workers, and the size of the plant.

Second, because the WECD contains much more information about a worker's employer than has been previously available, I am able to examine whether alternative characteristics of a worker's employer provide a better signal for the unobserved ability of a worker. While neoclassical explanations for the size-wage premium imply that large plants and firms employ more skilled workers, they differ on the mechanism driving this decision. For example, in the Oi model $(1983,1991)$, which hypothesizes that large employers employ more skilled workers due to higher monitoring costs, it is the number of workers in the plant that is positively correlated with the ability of workers in the plant. In the capital-skill complementarity model (Griliches 1969; Hamermesh 1980, 1993), which claims that large employers employ more skilled workers because they have more capital, total capital in a worker's plant provides the best measure of a worker's unobserved ability. Finally, in the Dunne and Schmitz (1992), which argues that large employers employ more skilled workers because they are more likely to employ skill-biased advanced technology capital, the type of capital used in the plant provides the best measure of the unobserved ability of workers. Having additional information about a worker's employer allows me to examine which of these three models is most consistent with the data.

The WECD is unique in its ability to address these issues because it is the largest employeremployee matched database available for the U.S. ${ }^{2}$ The WECD consists of approximately 200,000 manufacturing workers who responded to the 1990 Decennial Census long form, linked to over 16,000 separate manufacturing establishments. Once linked to data for a worker's employer available in the Longitudinal Research Database (LRD), these data provide not only worker characteristics such as age,

\footnotetext{
${ }^{2}$ See Abowd, Kramarz, and Margolis (1993) for a discussion of a matched database for French employers and employees.
} 
sex, race, and education, but also information about a worker's employer such as total output, total employment, labor costs, other input costs, capital stock, and investment. While the WECD has many attractive features, it is important to note that the WECD is not a random sample of either manufacturing workers or establishments (Troske 1993). As a result, this paper also explores the effects of the nonrandom sampling and presents results from several attempts to correct for the nonrandom sampling framework.

This paper reports three main findings. First, examining the cross-plant distribution of workers reveals a positive cross-plant correlation between the skill of managers, the skill of workers, and the size of the plant. Second, results from reduced form worker wage regressions show that controlling for both worker characteristics and the capital stock in a worker's plant eliminates the size-wage premium. In fact, including both measures of the amount and type of capital in a worker's plant along with total employment in wage regressions, leads to a negative size-wage premium. Finally, attempting to correct for possible selection bias does effect the parameter estimates, but the overall story remains the same -- including additional characteristics of a worker's employer in worker wage regressions eliminates the estimated size-wage premium.

These results are consistent with the neoclassical explanations for the size-wage premium which emphasize capital-skill complementarities and complementarities between worker skill and technological innovation. However, the primary significance of these results is that they show the employer size-wage premium can be accounted for with data linking worker and employer characteristics. As such, these results lend support to models which stress the important role of workeremployer matching in affecting the distribution of earnings (Sattinger 1993; Kremer 1993; Kremer and Maskin 1994).

The rest of the paper is as follows. Section II briefly outlines three neoclassical explanations for the size-wage premium. Section III discusses the data and documents possible problems. Section IV presents the empirical results. Section V summarizes and presents conclusions.

\section{Theoretical Explanations for the Size-Wage Premium}

Standard equilibrium theory suggests that a worker's wage should vary with worker characteristics that affect productivity: 


$$
\ln W_{t}=\alpha_{0}+\beta X_{i} u_{i}
$$

where $\mathrm{W}_{\mathrm{i}}$ is the observed wage of worker $\mathrm{i}, \mathbf{X}_{\mathrm{i}}$ is a vector of worker i's characteristics, and $\mathrm{u}_{\mathrm{i}}$ is an error term. In general, $\mathbf{X}_{\mathbf{i}}$ consists of characteristics such as age or experience, education, sex, race, marital status, and other variables that may affect a worker's marginal product. However, work has also focused on how the characteristics of a worker's employer might also affect a worker's wage. In these models equation (1) becomes:

$$
\ln W_{t}=\alpha_{0}+\beta X_{i}+\gamma Y_{i}+u_{i}
$$

where $\mathbf{Y}_{\mathbf{i}}$ is a vector of characteristics for worker i's employer. In general, the only employer characteristic available for workers has been total employment. Now equation (2) becomes:

$$
\ln W_{t}=\alpha_{0}+\beta_{t} X_{i}+\gamma_{L T E}(L T E)+\gamma_{L F T E^{*}}(L F T E)+u_{i}
$$

where LTE is the log of total employment in worker i's plant and LFTE is the log of total employment in worker i's firm. Work on the size-wage premium involves explaining why $\left(_{\text {LTE }}\right.$ and $\left(_{\text {LFTE }}\right.$ should be positive. $^{3}$

All three of the neoclassical explanations for the size-wage premium that I consider are based on the Lucas (1978) model of the size distribution of firms. Therefore let me begin by briefly reviewing this model. In the Lucas model each worker in the economy is endowed with a talent or skill for managing, which is parameterized by $\mathrm{x}$. Output from a firm managed by a type $\mathrm{x}$ manager is given by: $\mathrm{q}=\mathrm{xg}[\mathrm{f}(\mathrm{L}, \mathrm{K})]$, where $\mathrm{q}$ is total output, $\mathrm{f}(\cdot)$ is a constant return to scale production function, $\mathrm{L}$ is labor input, $\mathrm{K}$ is capital input, and $\mathrm{g}(\cdot)$ is a strictly increasing, concave function which guarantees that the best manager does not manage all inputs. In this model there exists some number $\mathrm{z}$ such that everyone with $x \$ z$ is a manager and everyone with $x<z$ is an employee. Managers choose $L$ and $K$ to maximize profits: $B=p x g[f(K, L)]-w L-r K$ where $p, w$, and $r$ are the per-unit prices of output, labor, and capital, respectively. In equilibrium the demand for $\mathrm{K}$ and $\mathrm{L}$ are an increasing function of $\mathrm{x}$-- the best managers manage the largest firms.

\footnotetext{
${ }^{3}$ The reader should note that is work examining the size-wage premium using panel data on workers which allows researchers to correct for person-specific unobserved ability. Even using panel data, there is still a significant size-wage premium (Brown and Medoff 1989).
} 
The first model of why large plants hire better workers is the Oi model (1983). In this model there are three inputs into the production function: $q=f(K, L, T)$ where $K$ is again capital, $T$ is the managers time, and $\mathrm{L}$ is labor input. $\mathrm{L}$ is given by: $\mathrm{L}=\mu 1$, where 1 is the number of workers and $\mu$ indexes the skill of the workers. $\mathrm{T}$ is given by: $\mathrm{T}=\mathrm{x}(\mathrm{H}-\mathrm{hl})$, where $\mathrm{x}$ is again a measure of managerial ability, $\mathrm{H}$ is the total number of hours a managers has, and $\mathrm{h}$ is the amount of time per worker that must be devoted to monitoring to ensure that workers provide the optimal effort. Managers choose K, 1, and $\mu$ to maximize: $B=\operatorname{pf}[\mu l, K, x(H-h l)]-r K-w(\mu) 1$, where the price of labor, $w(\mu)$, is now an increasing function of skill, $w \mathrm{~N} \mu)>0 .{ }^{4}$ In this model $\left(=\mathrm{pxhf}_{\mathrm{T}}\right.$ measures the per-worker monitoring cost and $\mathrm{w}(\mu)+($ is the full cost of hiring an additional worker. More skilled managers hire more skilled worker because more skilled workers produce more output per unit of monitoring. Like the Lucas model, this model implies that better managers manage larger firms. However, this model also implies that better managers also hire more skilled workers.

The second model of why large plants hire more skilled workers is the capital-skill complementarity model (e.g., Griliches 1969; Hamermesh 1980, 1993). In this model L is again given by: $\mathrm{L}=\mu 1$. This model assume that capital and skill are complements (in particular, the model assumes that capital and skill are q-complements so that $\left.{ }^{*} \mathrm{f}(\mathrm{K}, \mathrm{L}) /{ }^{*} \mathrm{~K}^{*} \mu>0\right)$. Now managers choose $\mathrm{K}, 1$ and $\mu$ to maximize profits: $B=\operatorname{pxg}[f(K, \mu l)]-w(\mu) L-r K$ where $w(\mu)$ is again an increasing function of $\mu$ :

$w \mathrm{~N} \mu$ ) $>0$. Notice that the demand for $\mathrm{K}$ and $\mathrm{L}$ is still increasing in $\mathrm{x}$. However, now the complementarity between $\mu$ and $\mathrm{K}$ induces more skilled managers to substitute towards more skilled workers. ${ }^{5}$ Similar to the Oi model, this model implies that the most skilled managers will manage the most capital and will also employ the most skilled workers. However, in the capital-skill complementarity model it is total capital stock, and not total employment, that is positively related to the skill of workers.

A final model of why large plants hire better workers is Dunne and Schmitz (1992). In this model managers and workers again differ in ability with total labor input given by $\mathrm{L}=\mu 1$ and with perunit labor cost given by $w(\mu)$ : w $N \mu)>0$. However, Dunne and Schmitz also allow capital to vary in ability. They assume that there are two types of capital, advanced-technology capital and standard

\footnotetext{
${ }^{4}$ All three models assume that $\mathrm{w}(\mu)$ is determined competitively in the market as in Rosen (1986), and that the plant can hire as many workers of a given skill level at $w(\mu)$.

${ }^{5}$ This is because as firms choose more capital, the benefit of choosing workers with more skill increases. However, the cost of hiring an additional unit of skill remains constant. Therefore, for a large enough capital stock, it pays to choose workers with more skill.
} 
capital, that it is more costly to employ advanced-technology capital, and that advanced technology capital is skill-biased. Now the managers problem is to choose the type of capital, the amount of capital, and the amount and skill of labor, conditional on her given skill x. Dunne and Schmitz show that the size of a firm is an increasing function of $x$, and that the probability of a plant adopting advanced technology capital is an increasing function of firm size. This in turn implies that the skill of the firm's workforce is also an increasing function of firm size. Similar to the previous models, this model implies that the best managers manage the largest plants and hire the most skilled workers. However, this model predicts that it is the type of capital that is positively correlated with worker ability.

Before moving on, let me relate these models back to equation (3) and why $\left(_{\text {LTE }}\right.$ and $\left(_{\text {LFTE }}\right.$ should be positive in estimates of this equation. In all three models the characteristics of worker i's employer provides a signal of worker i's unobservable ability. ${ }^{6}$ In particular, all three models predict that larger plants will employ a more skilled workforce. $\left(_{\text {LTE }}\right.$ and $\left(_{\text {LFTE }}\right.$ have a positive sign in estimates of equation (3) because they signal that the worker is of high quality. However, the three models differ as to what induces large employers to hire better workers. The Oi model suggests that large employers hire more skilled workers because of the rising monitoring costs with the number of employees. Thus, in the Oi model total employment in the plant provides the best signal of worker ability in the plant. In contrast, the capital-skill complementarity model implies that large employers hire more skilled workers because they have a larger capital stock. In this model cross-plant differences in the amount of capital, and not in total employment, provides the best measure of the ability of workers in the plant. $\left(_{\text {LTE }}\right.$ and $\left(_{\text {LFTE }}\right.$ are positive only because the amount of capital and labor used in a plant are positively correlated. Including measures for both the amount of capital in a worker's plant and total employment in a worker's plant, in estimates of equation (3) should result in a positive coefficient on capital and an insignificant coefficient on employment. Finally, in the Dunne and Schmitz model large employers hire more skilled workers because they are more likely to employ advanced-technology capital. In this model differences in the type of capital used in the plant, and not total employment, provides the best measure of the ability of workers in the plant. In the Dunne and Schmitz model $\left(_{\text {LTE }}\right.$ and $\left(_{\text {LFTE }}\right.$ have a positive coefficient in estimates of equation (3) only because total employment and the use of advanced technology capital are positively correlated across plants. Including a plant-level measure of the type of capital used in the plant, along with total employment, in estimates of equation (3) should result in a

\footnotetext{
${ }^{6}$ Unobservable to the econometrician but not to the employer.
} 
positive coefficient on the measure of the type of capital used in the plant and an insignificant coefficient on total employment.

\section{The Data}

The data used in this study come from the WECD and the LRD. The WECD is a crosssectional database containing manufacturing workers' responses to the 1990 Decennial Census long form, along with a link to establishment data in the LRD. The LRD is a panel database consisting of establishment responses to the Census of Manufactures (CM) and the Annual Survey of Manufactures (ASM). The construction of these two data sets, the information contained in each, and possible problems with the matched data, will be discussed in turn. ${ }^{7}$

The WECD was constructed by matching manufacturing worker records from the 1990 Sample Detail File (SDF) to establishment records in the 1990 Standard Statistical Establishment List (SSEL). The 1990 SDF consists of all household responses to the 1990 Decennial Census long form. The SDF contains the standard demographic information for workers collected in the Census, along with detailed location information and a three-digit Census Industry code for each respondent's place of work. The SSEL is a complete list of all manufacturing establishments in the U.S. in a given year. The SSEL contains detailed location information and a four-digit SIC code for each establishment along with a unique establishment identifier that is common to other Census Bureau economic surveys and censuses. Workers and establishments were matched using the detailed location and industry information available in both data sets. The first step in the matching process was to keep only establishments that were unique in an industry-location cell. Next, all workers indicating that they work in the same industry-location cell as an establishment were linked to the establishment. Then all matches based on imputed data were dropped. Finally, the establishment's unique identifier was appended to the workers' records. This identifier enables the worker data to be linked to employer data in the LRD. ${ }^{8}$

\footnotetext{
${ }^{7}$ This will be a brief discussion. For a more complete discussion of these databases see Troske (1993) and McGuckin and Pascoe (1988).

${ }^{8}$ The SSEL is used by the Census Bureau for conducting its various economic surveys and censuses. As such, it contains the street address for each establishment, along with geographic codes which identify an establishment's location down to the block level. However, other information for an establishment, such as the amount of inputs purchased or the total output produced in a given year, is only available from establishment responses' to censuses or surveys. Thus, once a worker record has been matched to an establishment in the SSEL, it still must be linked to the establishment's record in the LRD.
} 
The second data set used in the analysis is the LRD. The LRD consists of every CM since 1963 $(1963,1967,1972,1977,1982,1987)$ as well as the 1973-90 ASMs. ${ }^{9}$ To construct the data used in this analysis I link the WECD to the LRD using each establishment's identifier. Since the hours worked, weeks worked, and earnings data for workers in the WECD refers to 1989, I link the WECD records to establishments in the LRD in 1989. In addition, since capital stock data for plants are only available in Census years, I require all establishments in the data set to be in the LRD in both 1987 and 1989. Finally, to minimize the effect of outliers and reporting problems, I only select workers who are between 18 and 65 years old, who usually work between 30 and 65 hours a week, and who report earning between $\$ 2.50$ and $\$ 100.00$ an hour. ${ }^{10}$ The resulting data set contains 142,414 workers matched to 5407 establishments. ${ }^{11}$ From the WECD comes worker information such as age, education, sex, race, three-digit occupation, as well as usual hours worked last year, weeks worked last year, and annual earnings last year, all for 1989. These later three variables are used to construct an hourly wage rate for the worker. From the LRD comes employer information such as the total employment in both the plant and the firm, total capital stock and investment in the plant, the ownership structure, and the costs of other inputs used in the plant. ${ }^{12}$

One problem with the WECD in general, and the data used here in particular, is that they are not a random sample of either workers or establishments. Workers who work in large establishments

\footnotetext{
${ }^{9}$ The CMs are a complete census of all manufacturing establishments in a given year. The ASMs are a probability sample of establishments, surveyed over a five year period. A new ASM sample is drawn two years after a census, with the probability of an establishment being included in the ASM increasing with its total employment in the previous CM. Establishments with more than 250 employees in the previous CM are in the ASM with certainty. Thus, establishments that always have more than 250 employees will appear in every year in the LRD, while smaller establishments will only appear in the LRD in census years and for a five year period if they are in a given ASM.

${ }^{10}$ The 1990 Decennial Census asks workers to report the address of the establishment where they worked in the previous week. Keeping workers with these characteristics increases the probability that the worker was employed in the same establishment in 1989.

${ }^{11}$ The SDF contains 2,720,522 manufacturing workers who are between 18 and 65 years old, who usually worked between 30 and 65 hours a week and who had wages between $\$ 2.50$ and $\$ 100.00$ an hour. Thus, approximately $5 \%$ of the workers in the original data set are contained in the sample data set.

${ }^{12}$ See Table A1 in the appendix for a complete list of all variables available in the data set. In general, all plant variables are based on 1989 data with the exception of capital stock data which is based on 1987 data. All firm data are based on 1987 data. See Table 3 for a definition of all variables used in the analysis. In this analysis the term firm refers to all establishments owned by the same entity that are covered in the Census Bureaus various Economic Censuses. Establishments in the Transportation and Public Utility and Finance, Insurance, and Real Estate sectors are not included in Census Bureau economic censuses.
} 
are over represented in these data. This nonrandomness arises for two reasons. First, the matching process is more likely to match workers to large establishments and establishments located in urban areas (Troske 1993). This is because large establishments are more likely to be unique in an industrylocation cell, are more likely to contain workers who received a long form in the Decennial Census, and because more detailed location data are available for establishments located in urban areas. Second, large establishments are over represented in the ASM, and therefore are more likely to appear in the data.

Tables 1 and 2 and Figures 1-4 document some of the effects of the selection. Table 1 presents demographic characteristics for all manufacturing workers in the original SDF file that meet the selection criteria (column 2), and for all workers in the sample data set (column 3). To control for the fact that large plants are over represented in the ASM, the data for the sample workers are weighted using ASM sample weights. In general, there appears to be very little difference in the characteristics of workers in the two data sets. The matched file contains a slightly larger percentage of white, married, male workers. In addition, sample workers are slightly older and average about \$1300.00 in higher earnings in a year. The one major difference between workers in the two files is location. Sample workers are much more likely to be located in New England and the Midwest.

Figures 1 and 2 present the entire distribution for two of the more important demographic characteristics, wages (Figure 1) and education (Figure 2), These figures again reveal slight differences between workers in the two files. In general, the sample data set contains fewer workers at the low end of both the wage and educational distribution. $45 \%$ of workers in the SDF earn less than $\$ 10.01$ an hour, while only $35 \%$ of workers in the sample data set earn this little. $20 \%$ of the workers in the SDF have less than a high school diploma, while $18 \%$ of the workers in the sample data set report never finishing high school.

Table 2 presents summary statistics for all plants in the LRD in both 1989 and 1987 (column 2), and for all plants which contain workers in the sample data set (column 3). To again control for large plants being over represented in the ASM the plant data are weighted using the ASM sample weights. The numbers in Table 2 show quite clearly that large plants and plants located in urban areas are over represented in the sample data. The average employment for plants in the sample data is 187.3 while the average employment for LRD plants is 87.0. $87.3 \%$ of the sample plants are located in a Metropolitan Statistical Area (MSA) compared with 78.8\% of the LRD plants. Sample plants also have a much higher average investment and capital stock and are much more likely to be a part of a 
multi-establishment firm. Finally, similar to the distribution of sample workers, sample plants are more likely to be located in the New England and Midwest sections of the county.

To further explore possible nonrandomness in the sample data, Figure 3 presents the establishment size distribution for sample plants and for all plants in the LRD, while Figure 4 presents the establishment size distribution for matched workers and for all manufacturing workers in the May 1988 CPS. ${ }^{13}$ Figure 3 shows that the sample data contain more large establishments than the LRD. Almost $40 \%$ of establishments in the matched data have more than 100 employees, while only $18 \%$ of the plants in the LRD have more than 100 employees. Figure 4 tells a similar story for workers. $60 \%$ of all workers in the sample data work in establishments with 250 or more employees, while less that $50 \%$ of workers in the CPS report working in establishments with 250 or more employees.

The evidence in Tables 1 and 2 and Figures 1-4 regarding the nonrandomness of these data is mixed. In term of most demographic characteristics there appears to be little difference between workers in the SDF and workers in the final sample. However, it does appear that the sample data contains fewer workers at the low end of the wage and establishment size distribution. Therefore, whenever appropriate, I will compare the results from analysis on these data with previously established results based on alternative data sources. In addition, in the empirical section I assess the effect of the selection, and control for possible bias introduced because the data are not a random sample of the population. However, these tests are in no way conclusive and the reader should keep in mind possible problems with the data when assessing the results that follow.

\section{Empirical Investigation of the Size-Wage Premium}

\section{A. Relationship Between the Skill of Managers, the Skill of Workers, and the Size of the Workplace.}

One implication of all three theoretical explanations for the employer size-wage premium is that more skilled managers work in larger plants with more skilled workers. To examine this hypothesis Table 4 presents the results from regressing plant-level measures of the skill of one group of

\footnotetext{
${ }^{13}$ Unfortunately, the CPS provides a poor comparison to the sample data because $15 \%$ of workers in the CPS either do not know or do not report the size of their establishment. The distribution shown in Figure 2 does not include any of these workers. If it is the case that the probability of not knowing or not reporting establishment size is positively correlated with the size of a worker's establishment, as seems likely, the CPS will understate the "true" establishment size distribution for workers.
} 
workers (i.e., production workers) on plant-level measures of the skill of the other group of workers (i.e., managers) along with various measures of size. ${ }^{14}$ For production workers the plant-level measure of skill is the percentage of production workers in the plant with at least some college (EducP). For managers the plant-level measure of skill is the percent of managers in the plant with at least a Bachelor's Degree $(\text { EducM })^{15}$

While all three models imply that more skilled managers and workers work in larger plants, they disagree on the best measure of size. In the Oi (1983) model employment is the appropriate size measure. Therefore, Columns (1) in Table 4 report results where the log of total employment in the plant (LTE) and the firm (LFTE) are used as the size measure. In the capital-skill complementarity model capital is the appropriate measure of size. Therefore, Columns (2) in Table 4 report results using the log of the capital stock in the plant $(\mathrm{K})$ as the size measure. ${ }^{16}$ Finally, in the Dunne and Schmitz (1992) model the type of capital used in the plant is the appropriate measure of size. Unfortunately, the WECD does not contain any information on the type of capital used in the plant. However, empirical evidence shows that investment at the plant is positively correlated with the presence of advancedtechnology capital (Dunne 1991). Therefore, Columns (3) in Table 4 report results where the log of the average investment in the plant in 1987 and 1989 is used as the size measure. ${ }^{17}$ The EducP regression are where the skill of production workers is regressed on the skill of managers and the various size measures, while the EducM regressions are where the skill of managers are regressed on the skill of production workers and the various size measures.

If there has been an increasing trend in overall education among workers then it may appear that more educated managers work with more educated workers simply because younger workers are more likely to work together. To control for this the age of the plant (PltAge) is included in all of the regressions in table $4 .{ }^{18}$ Controls for whether the plant is part of a multi-plant firm (MU), the plant's

\footnotetext{
${ }^{14}$ Production workers are workers with a three-digit occupation code greater than 500, managers are workers with a three-digit occupation code less than 200 (U.S. Census Bureau 1992).

15 The plant-level measures of the education of production workers and managers are constructed this way because education is a class variable in the Decennial Census. See Table 3.

${ }^{16}$ See Table 3 for a description of how $\mathrm{K}$ is measured.

${ }^{17}$ I use the average investment in the plant over a two year period to overcome the lumpy nature of plant-level investment (Doms and Dunne 1993).

${ }^{18}$ In general older plants contain older workers (Brown and Medoff 1993).
} 
two-digit industry, region, and a dummy variable indicating whether the plant is located in an MSA, are also included in all of these regressions. Table 3 provides a description of all of the variables appearing in Table 4.

The positive coefficients on EducM in the EducP regressions, and on EducP in the EducM regressions indicate that across plants the skill of managers is positively correlated with the skill of workers. In addition, the positive coefficients on LTE and LFTE in Columns (1), K in Columns (2) and Linvest in Columns (3) show that larger plants and firms do contain more skilled workers, regardless of the measure of size. ${ }^{19}$ Overall, the results in Table 4 support the hypothesis that more skilled managers work with more skilled workers in larger plants.

\section{B. Relationship Between Worker Wages and Employer Characteristics.}

i. Estimation Strategy

To start with let me outline the empirical strategy followed in this section. The basic estimating equation is:

$$
\ln W_{t}=\alpha_{i}+X_{i} \beta+Y_{i} \gamma+u_{t}
$$

where $\mathrm{W}_{\mathrm{i}}$ is the wage of worker $\mathrm{i}, \mathbf{X}_{\mathbf{i}}$ is a vector of worker i's characteristics, $\mathbf{Y}_{\mathbf{i}}$ is a vector of characteristics of worker i's employer, and $\mathrm{u}_{\mathrm{i}}$ is a worker specific error term.

The first step in the analysis is to estimate equation (4) including a complete set of worker characteristics in $X_{i}$ and setting $(=0$. This is done for two reasons. First, given the possible problems with the data mentioned above, there is some question about whether these data are appropriate for estimating reduced form worker wage regressions. Estimating equation (4) setting ( $=0$ allows a comparison between cross-sectional parameter estimates from these data with previously reported parameter estimates from similar cross-sectional wage regressions based on CPS type data.

Second, the results from this regression can be used to further test the hypothesis that more skilled managers manage more skilled workers in larger establishments and firms. If this hypothesis is

\footnotetext{
${ }^{19}$ I repeat the entire analysis using a number of alternative plant-level measures of skill such as the percent of both types of workers with at least a high school diploma, the percent of both types of workers with at least some college, and the percent of both types of workers with at least a Bachelor's Degree. The results remain the same.
} 
true then the return to observable measures of skill, such as education, should fall when characteristics of worker i's employer are included in equation (4). Along these lines, the next two steps in the analysis are to estimate equation (4) setting \$=0 and including LTE, LFTE in $Y_{\mathrm{i}}$ and then to estimate equation (4) including the complete set of worker characteristics in $\mathbf{X}_{\mathbf{i}}$ along with LTE and LFTE in $\mathbf{Y}_{\mathbf{i}}$. Again, if it is the case that more skilled workers work in larger establishments and firms, then the coefficients on LTE and LFTE should fall when equation (4) includes controls for both worker ability and plant characteristics. In addition, comparing the estimated size-wage premium from this regression with previously established estimates of the size-wage premium based on alternative data sources provides another check on the data. Finally, results from the regression including both worker and plant characteristics will serve as a benchmark for regressions where alternative characteristics of worker i's employer are included in equation (4).

The next step in the analysis is to sequentially include additional characteristics of a worker's employer in equation (4). As mentioned above, the capital-skill complementarity model implies that it is plant-level differences in capital, not employment, that provides the best measure of worker ability in the plant. To test this hypothesis, I estimate equation (4) including the log of plant and firm employment (LTE and LFTE ) along with the log of the capital stock in the plant (K) in $\mathbf{Y}_{\mathbf{i}}$. If the capital-skill complementarity hypothesis is true including $\mathrm{K}$ in $\mathbf{Y}_{\mathbf{i}}$ when estimating equation (4) should lead to smaller coefficients on LTE and LFTE.

The second hypothesis is that it is the type of capital used in the plant that is the best proxy for the unobserved ability of workers in the plant and firm. To test this hypothesis I include the log of the average investment at the plant in 1987 and 1989 (LInvest) in $\mathbf{Y}_{\mathbf{i}}$ to control for the type of capital in the plant. Here the hypothesis is that including LInvest in $\mathbf{Y}_{\mathbf{i}}$ should reduce the coefficient on LTE and LFTE in estimates of equation (4).

The final step in the estimation procedure is to correct for possible biases in the parameter estimates resulting from the nonrandomness of the data. If we let:

\section{$I_{i}= \begin{cases}1 & \text { if a worker in the SDF appears in the WECD } \\ 0 \text { otherwise }\end{cases}$}

then the basic problem is that parameter estimates from equation (4) may be biased because $\mathrm{E}\left(\mathrm{u}_{\mathrm{i}} \mid \mathrm{I}_{\mathrm{i}}=1\right) . .0$.

I employ two methods to correct for this possible bias. The first assumes that the probability of a worker being in the sample is simply a function of the size of a worker's establishment -- $\mathrm{I}_{\mathrm{i}}=\mathrm{f}(\mathrm{Plant}$ 
Employment). If this is the case then weighting the data so that the establishment size distribution of matched workers resembles the "true" establishment size distribution will produce unbiased estimates of the parameters. One source of information about the "true" worker establishment size distribution is the observed worker establishment size distribution in the May 1988 CPS. ${ }^{20}$ Therefore, I weight the establishment size distribution for matched workers so that it resembles the establishment size distribution for manufacturing workers in the CPS. ${ }^{21} \mathrm{I}$ then reestimate all of the regressions using these weights.

The second method to correct for possible bias assumes a more complicated selection mechanism. There are two conditions that a worker must meet to appear in the matched data. First, a worker must have nonimputed data, and second a worker must work in an establishment that is unique in an industry-location cell (Troske 1993). If the joint probability of these two events occurring is related to the characteristics of the worker, then $\mathrm{I}_{\mathrm{i}}$ is some function of these characteristics:

$$
I_{i}-f\left(X_{i} \beta\right)
$$

where $X_{i}$ is again a vector of worker i's characteristics. ${ }^{22}$ Heckman (1976) shows that, assuming the error terms are normally distributed, the correct way to adjust for the selection is to first estimate a probit model based on equation (5), and then to include the estimated inverse Mill's ratio from this regression as an independent variable in equation (4). Equation (4) then becomes:

$$
\operatorname{Ln} W_{i} \alpha_{0}+X_{i} \beta+Y_{i} \gamma+\frac{\hat{\phi}_{i}}{\hat{\Phi}_{i}} \delta+v_{i}
$$

with $\mathbf{M} / \mathbf{M}$ being the estimated inverse Mill's ratio. Thus, the second method is to estimate $\mathbf{m} / \mathbf{M}$ from a probit model based on equation (5), and to then estimate equation (6).

\footnotetext{
${ }^{20}$ See footnote 13 for a discussion of why the establishment size distribution for workers in the CPS may be a biased estimate of the "true" establishment size distribution of workers.

${ }^{21}$ For example, since $0.2 \%$ of all workers in the matched data work in establishments with fewer than 10 workers, while $8.1 \%$ of workers in the CPS report working in similar size establishments, I give all matched workers who work in establishments with less than ten employees a weight of 40.50 .

${ }^{22}$ Research at the Census Bureau (Bates, Fay and Moore 1991) suggests that I is a function of a worker's age, income, education, race, and whether or not a worker is living with relatives.
} 


\section{ii. Estimation Results \\ a. Replicating Previous Results}

Column (1) in Table 5 presents the results from estimating equation (4) including the full set of worker characteristics in $\mathbf{X}_{\mathbf{i}}$ and setting ( $=0$. Column (2) presents the results from estimating equation (4) setting \$=0 and including LTE, LFTE, and a control for the ownership structure of the establishment (MU) in $\mathbf{Y}_{\mathbf{i}}$. Column (3) presents the results from estimating equation (4) including the full set of worker characteristics in $\mathbf{X}_{\mathbf{i}}$ and the three employer characteristics in $\mathbf{Y}_{\mathbf{i}}$. Table 3 provides a complete list and description of all the variables used in the analysis. In addition to the variables listed in the table, all regressions in this analysis include controls for four-digit industry, Census region, and an interaction between an MSA dummy variable and region. The regressions in columns (1) and (3) also include controls for a worker's three-digit occupation. ${ }^{23}$

The parameter estimates reported in Column (1) in Table 5 closely resemble estimates from previous cross-sectional wage regressions. The coefficient estimates on the experience and education terms are very similar to those reported by Mincer (1974) among others. In addition, the coefficient estimates on the sex and marriage interactions are similar to the coefficients found by previous researchers examining gender differences in wages and the wage premium received by married male workers (Carrington and Troske 1993; Hellerstein and Neumark 1993; Daniel 1993). ${ }^{24}$

The results in column (2) show that estimating equation (4) setting $\$=0$ produces a large estimated size-wage premium. The coefficient of 0.065 on LTE in column (2) shows that workers in plants with log employment one standard deviation above mean log employment receive $19.1 \%$ higher wages than workers in plants with log employment one standard deviation below mean log

\footnotetext{
${ }^{23}$ Since it is unclear whether industry and location is an employer or a worker characteristic, I have included these variables in all regressions. However, occupation seems clearly identified with a worker, so I have only included occupation when worker characteristics are included in the regression.

${ }^{24}$ One exception is that the coefficients on race, in particular blacks, appear to be quite low (Cain 1986; Carrington, McCue and Pierce 1993). There are a number of potential reasons why these estimates are so low. First, these regressions include both male and female workers so the race coefficient will be an average of the racial difference in wages for both men and women. In general, the wage differential for black women is much smaller than the wage differential for black men, so this may lower the estimated wage differential. Second, I include much more detailed industry and occupation controls in these regressions than is common. If a large part of the black-white wage differential is due to industry and occupation then this would also serve to compress the estimated wage differentials.
} 
employment. ${ }^{25}$ The coefficient of 0.026 on LFTE shows that workers in firms with log employment one standard deviation above the mean receive $11.5 \%$ higher wages that workers in firms with $\log$ employment one standard deviation below the mean.

The coefficient estimates on LTE and LFTE in Column (3) in Table 5 are both encouraging and revealing. The estimates are encouraging because they are similar in magnitude to the establishment and firm size-wage premia found in earlier work. The 0.050 coefficient on LTE shows that workers in plants with log employment one standard deviation above the mean receive $14.7 \%$ higher wages than workers in plants with log employment one standard deviation below the mean. The 0.020 coefficient on LFTE in the same regression shows that workers in firms with log employment one standard deviation above the mean earn $8.8 \%$ higher wages than workers in firms with log employment one standard deviation below the mean. Brown and Medoff (1989) review the results from a number of previous studies of the size-wage premium and report estimated establishment size-wage premium of $6-15 \% .^{26}$ The estimate of $14.7 \%$ from these data is certainly within this range. Brown and Medoff also report that previous estimates of the firm size-wage premium are generally smaller than estimates of the establishment size-wage premium. Again this is exactly what is found in these data.

These results are revealing because they provide further support for the hypothesis that more skilled workers work in large establishments. Comparing the coefficients on LTE and LFTE in columns (2) and (3) shows that both the establishment and firm size-wage premia fall by $23 \%$ once I control for the observable skill of the worker. In addition, comparing the coefficients on the education variables in columns (1) and (3) shows that the estimated return to education falls once I control for the size of a worker's establishment and firm.

Table 6 presents results from the same regressions reported in Table 5 estimated separately for Managers and Production Workers. The results in Table 6 mirror the results in Table 5. Comparing

\footnotetext{
${ }^{25}$ The establishment size-wage premium is calculated as the log difference in the wage of a worker in a plant with log employment one standard deviation above then mean and the wage of a worker in a plant with log employment one standard deviation below then mean. The wage of a worker in a plant with log employment one standard deviation above the mean is the product of the coefficient on LTE and the log employment of a plant one standard deviation above the mean. The mean and standard deviation of plant and firm log employment are given in Table A2. The firm size-wage premium is computed in a like fashion.

${ }^{26}$ One thing to note. Almost all previous estimates of the size-wage premium included a control for union status, either directly by knowing the union status of the worker, or indirectly by including the percent of workers in a three-digit industry covered by a union contract. I do neither for two reasons. First, the WECD contains no direct information on a worker's union status. Second, once I include four-digit controls in these regressions the effect of the percent of workers covered by a union contract in a worker's three-digit industry becomes insignificant.
} 
the coefficients on the education dummy variables in columns (1) and (3) shows that the estimated returns to education for managers and production workers fall once I control for the size of a worker's establishment and firm (although the fall for managers is extremely small and concentrated among highly educated managers). Comparing the coefficients on LTE and LFTE in columns (2) and (3) shows that for both managers and workers the estimated size-wage premia decline once I control for the observed ability of workers. Again this supports the earlier finding that both more skilled managers and more skilled production workers work in larger plants and firms.

Comparing the size-wage premium for managers with the premium for production workers shows that production workers receive a much larger size-wage premium than managers. The coefficient of 0.037 on LTE in column (3) of the Managers regression shows that managers receive a $10.9 \%$ establishment size-wage premium, while the coefficient of 0.005 on LFTE in the same regression shows that managers receive a $2.2 \%$ firm size-wage premium. The coefficient of 0.057 on LTE in column (3) in the Production Worker regression shows that production workers receive a $16.8 \%$ size-wage premium, while the coefficient of 0.025 on LFTE in the same regression shows that these workers receive a $11.1 \%$ firm size-wage premium. One possible explanation for this difference is that managers in large establishments or firms receive a larger percentage of their total compensation in benefits, such as stock options, nicer offices, or the use of a company car. Since these benefits would not appear in reported earning for managers this would cause a downward bias in the estimated sizewage premium. ${ }^{27}$ Unfortunately, there is no way to check this hypothesis in the data.

To summarize, there are three main findings drawn from Tables 5 and 6 . First, the results from these tables show that these data are capable of replicating previous documented relationships between worker characteristics and wages. This suggests that these data can be used to investigate the sizewage premium. However, this is in no way conclusive and I will examine the robustness of the findings in a later section. Second, these results provide further support for the hypothesis that more skilled workers and more skilled managers work together in larger establishments and firms. Finally, the results in Tables 5 and 6 show that production workers exhibit a larger size-wage premium than

\footnotetext{
${ }^{27}$ Another explanation for this difference may lie in the way these data are collected. The ASM and CM are establishment based surveys and only include actual production units. If a plant is part of a multi-plant firm, and the headquarter of the firm is not part of a production unit, then the headquarter will not be included in the data. Thus, managers in these data are a select group, they are managers who work in production units. In contrast, all production workers will work in a production unit so all production workers have an equally likely chance to appear in the data.
} 
managers. I now turn to exploring whether alternative characteristics of a worker's employer provide a better signal for the unobserved skill of the worker.

b. Including Additional Employer Characteristics

Table 7 presents the results from estimating equation (4) including the full set of worker characteristics in $\mathbf{X}_{\mathbf{i}}$ and including additional characteristics for a worker's employer in $\mathbf{Y}_{\mathbf{i}}{ }^{28}$ Column (1) in Table 7 presents the results from estimating equation (4) including the log of the capital stock in the plant (K) along with LTE and LFTE in $\mathbf{Y}_{\mathbf{i}}$. Column (2) presents the results from estimating equation (4) including the log of the average investment in the plant in 1987 and 1989 (LInvest) along with LTE and LFTE in $\mathbf{Y}_{\mathbf{i}}{ }^{29}$ Finally, column (3) presents the results from estimating equation (4) including LTE, LFTE, $\mathrm{K}$, and LInvest in $\mathbf{Y}_{\mathbf{i}}$. In addition to the variables listed in the table, all regressions include controls for the four-digit industry, three-digit occupation, Census region, and an interaction between region and MSA.

Comparing the estimated size-wage premium in column (1) with column (3) in Table 5 shows that including $\mathrm{K}$ in $\mathbf{Y}_{\mathbf{i}}$ substantially reduces the estimated size-wage premium. The coefficient of 0.004 on LTE in column (1) translates into only a $1.2 \%$ establishment size-wage premium which is $92 \%$ smaller than the establishment size-wage premium in Table 5. The coefficient of 0.014 on LFTE translates into a $6.2 \%$ firm size-wage premium which is $30 \%$ smaller than the firm size-wage premium in Table 5. This is exactly the prediction of the capital-skill complementarity model. It appears from these results that plant-level differences in capital stock, and not plant-level differences in employment, provide the best measure of worker ability.

The results in column (2) in Table 7 are similar. Including LInvest in $Y_{i}$ when estimating equation (4) leads to a slightly smaller estimated firm size-wage premium, and a much smaller estimated establishment size-wage premium. The coefficient of 0.012 on LTE in column (2) translates into a $3.5 \%$ establishment size-wage premium, which is $76 \%$ smaller than the estimate in Table 5. The coefficient of 0.019 on LFTE in column (2) translates into a $8.4 \%$ firm size-wage premium, which is

\footnotetext{
${ }^{28}$ The worker characteristics included in the regressions reported in Table 7 are identical to the characteristics included in the regressions in Table 5. However, to conserve space, I do not report the coefficients on many of these characteristics because they are almost identical their value reported in Table 5.

${ }^{29}$ In addition, an interaction between plant age and LInvest (LInvest*PltAge) is included in $\mathbf{Y}_{\mathbf{i}}$ in Table 7 to control for age related differences in plant investment.
} 
5\% smaller than the firm size-wage estimate in Table 5. Again, this is exactly the prediction of the Dunne and Schmitz model. It appears from these results that plant-level differences in the type of capital used in the plant, and not total employment, is the best measure of worker ability in the plant.

The results in column (3) show that including both $\mathrm{K}$ and LInvest in $\mathbf{Y}_{\mathbf{i}}$ leads to a negative establishment size-wage premium. The coefficient of -0.007 on LTE in column (3) shows that workers in plants with log employment one standard deviation above the mean receive $2.1 \%$ lower wages than workers in plants with log employment one standard deviation below the mean. However, the coefficient of 0.019 on LFTE shows that even after controlling for the additional employer characteristics, workers still receive a $6.7 \%$ firm size-wage premium. ${ }^{30}$

One possible reason for these low estimates of the establishment and firm-size wage premia could be the problem mentioned earlier -- if a larger percentage of the total compensation of managers in large firms and establishments comes in the form of larger benefits then this could produce a downward bias in the estimated size-wage premium. To see whether this is the case Table 8 presents the results from identical regressions estimated separately for Managers and Production Workers.

The results in Table 8 mirror the results seen in Table 7. Controlling first for $\mathrm{K}$ in columns (1), and then for LInvest in columns (2) produces much smaller estimates of the establishment and firm size-wage premia than seen in Table 6. In addition, the results in columns (3) show that including both $\mathrm{K}$ and LInvest in $\mathbf{Y}_{\mathbf{i}}$ produces a negative establishment size-wage premium (although the estimate for managers is insignificant). ${ }^{31}$

These findings are very similar to previous findings of Entorf and Kramarz (1993) and Dunne and Schmitz (1994). Entorf and Kramarz, using linked employer-employee data for French workers and firms, finds that controlling for capital stock in regressions similar to equation (4) leads to substantially lower estimates of the establishment and firm size-wage premia. Dunne and Schmitz,

\footnotetext{
${ }^{30}$ One explanation for these results could be that LTE, K and LInvest are perfectly collinear. To check this possibility Table A3 in the appendix presents the correlation coefficients for the correlation between LTE, $\mathrm{K}$, and LInvest, and the cross-industry mean of separate correlations of these variables by four-digit industry. These results show that while these variables are strongly linearly related, they are not perfectly linearly related. Given the large sample size it should be possible to distinguish between the effects of LTE, K and LInvest on log wages in these regressions.

${ }^{31}$ The estimated establishment size-wage premium in columns (1) in Table 7 is insignificant for managers and is $2.1 \%$ for production workers while the estimated firm size-wage premium is $0.6 \%$ for managers and is $7.9 \%$ for production workers. In columns (2) the estimated establishment size-wage premium is $3.5 \%$ for managers and $4.7 \%$ for production workers while the estimated firm size-wage premium is $0.6 \%$ for managers and $10.2 \%$ for production workers.
} 
using plant-level manufacturing data, find that controlling for the type of capital used in the plant also leads to lower estimated establishment and firm size-wage premia.

To summarize, the results from Tables 7 and 8 show that including alternative characteristics of a worker's employer in reduced form wage regressions substantially reduces, and even reverses, the estimated size-wage premium. These results are consistent with the capital-skill complementarity model which suggests that the amount of capital in a plant will be the best measure of the ability of workers in the plant and the model of Dunne and Schmitz which suggests that the type of capital in the plant will be the best measure of the ability of workers in the plant.

\section{c. Controlling for the Effects of Selection}

To examine the robustness of the previous results, Table 9 presents the results from estimating equation (4) weighting the data so that the establishment size distribution for workers in the data matches the establishment size distribution for workers in the May 1988 CPS. ${ }^{32}$ Table A4 in the appendix gives the weights used. Table 10 reports the results from estimating equation (4) including the estimated inverse Mill's ratio from a probit estimation of the conditional probability that a worker appears in the matched data. The parameter estimates from the probit regression are given in Table A5 in the appendix. The results in columns (1) of Tables 9 and 10 are for regressions where LTE and LFTE are included in $\mathbf{Y}_{\mathbf{i}}$, columns (2) report the results including $\mathrm{K}$ in $\mathbf{Y}_{\mathbf{i}}$, columns (3) reports the results including LInvest in $\mathbf{Y}_{\mathbf{i}}$ and columns (4) reports the results when LTE, LFTE, K and LInvest are included in $\mathbf{Y}_{\mathbf{i}}$. Included in all of these regressions are controls for four-digit industry, three-digit occupation, region and a region-MSA interaction.

The results from Table 9 show that while weighting the data does change the point estimates, the general findings from Tables 5-8 do not change. In column (1) the estimated establishment and firm size-wage premia are $13.5 \%$ and $8.4 \%$, respectively. These estimates are smaller than the estimates in column (3) in Table 5, but are well within the range reported by Brown and Medoff (1989). Column (2) shows that including $\mathbf{K}$ in $\mathbf{Y}_{\mathbf{i}}$ results in an estimated establishment and firm sizewage premia of $3.8 \%$ and $2.0 \%$, respectively, which is a drop of $72 \%$ in the establishment size-wage premium and $76 \%$ in the firm size-wage premium. Column (3) shows that including LInvest in $\mathbf{Y}_{\mathbf{i}}$ results in an estimated establishment and firm size premia of $6.1 \%$ and $7.5 \%$, respectively, which is a

\footnotetext{
${ }^{32}$ Footnote 13 discusses why the size distribution of workers in the CPS may itself be biased.
} 
drop of $55 \%$ in the establishment size-wage premium and $11 \%$ in the firm size-wage premium. Finally, column (4) shows that including both $\mathrm{K}$ and LInvest in $\mathbf{Y}_{\mathbf{i}}$ along with LTE and LFTE leads to an insignificant establishment size-wage premium, and a 5.3\% firm size-wage premium.

Table 10 shows that controlling for possible selection bias by including the inverse Mill's ratio in equation (4) leads to similar conclusions -- the individual point estimates of the size-wage premium change, but the general findings from Tables 5-8 remain. Column (1) shows that including just LTE and LFTE in $\mathbf{Y}_{\mathbf{i}}$ leads to an estimated establishment size-wage premium of $10.6 \%$ and $7.5 \%$. These estimates are even smaller still, but are still well within the range reported by Brown and Medoff (1989). Column (2) shows that adding $\mathbf{K}$ to $\mathbf{Y}_{\mathbf{i}}$ leads to an insignificant estimate of the establishment size-wage premium, and a 5.3\% firm size-wage premium. Column (3) shows that adding LInvest to $\mathbf{Y}_{\mathbf{i}}$ leads to an estimated establishment and firm size-wage premia of $1.8 \%$ and $7.0 \%$, respectively. Finally the results in column (3) shows that including both $\mathrm{K}$ and LInvest in $\mathbf{Y}_{\mathbf{i}}$ leads to an estimated establishment and firm size-wage premia of $-3.2 \%$ and $5.8 \%$, respectively.

The general conclusion from Tables 9 and 10 is that the results in Tables 5-8 are robust to corrections for sample selection bias.

\section{Conclusion}

This paper uses employer-employee matched data to examine whether the size-wage premium is the result of large employers hiring more skilled workers. The main findings are: 1) Examining the cross-plant distribution of the skill of workers shows that managers with larger observable measures of skill work in large plants and firms with production workers with larger observable measures of skill. 2) Results from reduced form wage regressions show that including measures of the amount or type of capital in a worker's plant significantly reduces the estimated size-wage premium. 3) These results are robust to efforts at correcting for possible bias in the parameter estimates due to sample selection.

The overall conclusion of this paper is that the evidence is consistent with neoclassical explanations for the size-wage premium -- the size-wage premium is the result of large employers employing more skilled workers. In particular, the evidence is consistent with models that posit that large employers hire more skilled workers due to capital and skill being complements in production, or

large employers being more likely to employ skill-biased advanced technology capital. However, these results are significant primarily because they show that the employer size-wage premium can be accounted for with data that links employer and employee characteristics. This is in contrast to previous efforts to account for this phenomenon using data with just worker or just employer 
characteristics (Mellow 1982; Brown and Medoff 1989; Davis and Haltiwanger 1991; Dunne and Schmitz 1994). This suggests that there are important interactions between the characteristics of workers and the characteristics of employers that are not being captured with data containing just worker or just employer characteristics. As such, these results lend support to models which emphasize the role of employer-employee matching in explaining both cross-sectional and dynamic aspects of the wage distribution (Sattinger 1993; Kremer 1993; Kremer and Maskin 1994).

As a caveat, I should mention that there are other possible ways in which the behavior of employers and employees could vary by size that are consistent with these findings. For example, recent research on training finds that large employers are much more likely to offer training, and that employees of large employers are much more likely to invest in firm specific training (Barron, Black and Lowenstein 1987; Holtman and Idson 1991; Flynn 1993; and Idson 1993). If this is the case then large employers may not be hiring better workers, but they may be providing them with more firm specific training (presumably making them "better" workers after the training). ${ }^{33}$ If this raises a worker's marginal product, and the worker is able to capture some of this increase, then the size-wage premium may be the result of a greater incidence of training among large employers.

\footnotetext{
${ }^{33}$ The Barron, Black and Loewenstein (1987) results indicate that both are true. Large employers hire better workers and also provide them with more training.
} 


\section{References}

Abowd,John, Francis Kramarz and David Margolis. "High Wage Workers and High Wage Firms: Compensation Policies and Firm Performance in France." mimeo Cornell University (March 1993).

Barron, John, Dan A. Black, and Mark A. Loewenstein. "Employer Size: The Implications for Search, Training, Capital Investment, Starting Wages, and Wage Growth." Journal of Labor Economics 5 (January 1987): 76-89.

Bates, Nancy, Robert E. Fay, and Jeffery C. Moore. "Lower Mail Response in the 1990 Census: A Preliminary Interpretation." In 1991 Annual Research Conference ProceedingsWashington D.C.: Bureau of the Census 1991.

Brown, Charles and James Medoff. "The Employer Size-Wage Effect." Journal of Political Economy 97 (November 1989): 1027-1059.

. "Firm Age and Labor Market Outcomes." mimeo University of Michigan (April 1993).

Brown, Charles, James Hamilton and James Medoff. Employers Large and Small. Cambridge, MA: Harvard University Press, 1990.

Cain, Glen. "The Economic Analysis of Labor Market Discrimination: A Survey." In Handbook of Labor Economics edited by Orley C. Ashenfelter and Richard Layard. Amsterdam: North Holland, 1986.

Carrington, William J. and Kenneth R. Troske. "Gender Segregation in Small Firms." Discussion Paper no. 92-13 Washington D.C.: Bureau of the Census, Center for Economic Studies, May 1993.

, Kristin McCue and Brooks Pierce. "Public Sector Employment and Black Economic Progress." mimeo Johns Hopkins University (October 1993).

Daniel, Kermit. "Does Marriage Make Workers More Productive?" PhD. dissertation, University of Chicago, August 1993.

Davis, Steve J., and John Haltiwanger. "Wage Dispersion Between and Within U.S. Manufacturing Plants, 1963-1986." In Brookings Papers on Economic Activity(1991): 115-200.

and Scott Schuh. "Small Business and Job Creation: Dissecting the Myth and Reassessing the Facts." Working Paper No. 4492 Cambridge, MA: NBER, October 1993.

Doms, Mark and Timothy Dunne. "Capital Adjustment Patterns in Manufacturing Plants." mimeo Center for Economic Studies, U.S. Census Bureau. (1994).

Dunne, Timothy. "Technology Usage in U.S. Manufacturing Industries: New Evidence from the Survey of Manufacturing Technology." Discussion Paper No. 91-7 Washington D.C.: Bureau of the Census, Center for Economic Studies, November 1991. 
Dunne, Timothy and James A. Schmitz. "Wages, Employment Structure and Employer Size-Wage Premia: Their Relationship to Advanced-Technology Usage at U.S. Manufacturing Establishments." Discussion Paper No. 92015 Washington D.C.: Bureau of the Census, Center for Economic Studies, December 1992.

"Wages, Employment Structure and Employer Size-Wage Premia: Their Relationship to Advanced-Technology Usage at U.S. Manufacturing Establishments." forthcoming Economica 1994.

Entorf, Horst, and Francis Kramarz. "The Impact of New Technologies on Wages and Skills: Lessons from Matching Data on Employees and on Their Firms." mimeo.

Flynn, Patrice. "Employer-Provided Job Training: For Whom and For What?" mimeo Washington D.C.: The Urban Institute (May 1993).

Griliches, Zvi. "Notes on the Role of Education in Production Functions and Growth Accounting." In Education, Income, and Human Capital edited by W. Lee Hansen. New York: NBER 1970.

Hamermesh, Daniel S. "Commentary." In The Economics of Firm Size, Market Structure and Social Performance, edited by John J. Siegfried. Washington D.C.: Federal Trade Commission, 1980. . Labor Demand. Princeton, NJ: Princeton University Press, 1993.

Heckman, J. "The Common Structure of Statistical Models of Truncation, Sample Selection and Limited Dependent Variables and a Simple Estimator for Such Models." Annals of Economic and Social Measurement 5 (1976): 475-92.

Hellerstein, Judith K. and David Neumark. "Sex, Wages, and Productivity: An Empirical Analysis of Israeli Firm-Level Data." mimeo 1993.

Holtman, Alphonse G. and Todd L. Idson. "Employer Size and On-the-Job Training Decisions." Southern Economic Journal. vol 58 no 2 (October 1991): 339-355.

Idson, Todd L. "Employer Size and Labor Turnover." Columbia University Discussion Paper No. 673. New York (November 1993).

King, W. I. Employment, Hours, and Earnings in Prosperity and Depression, United States 1920-1922. New York: National Bureau of Economic Research 1923.

Kremer, Michael. "The O-Ring Theory of Economic Development." The Quarterly Journal of Economics. Vol. CVIII No. 3. (August 1993): 551-575. , and Eric Maskin. "Segregation by Skill and the Rise in Inequality." mimeo February 1994.

Lucas, Robert E. "On the Size Distribution of Business Firms." The Bell Journal of Economics 9 (Spring 1978): 508-523. 
McGuckin, Robert and George Pascoe. "The Longitudinal Research Database (LRD): Status and Research Possibilities." Survey of Current Business (November 1988): 30-37.

Mellow, Wesley. "Employer Size and Wages." Review of Economics and Statistics. 64 (August 1982): 495-501.

Moore, H.L. Laws of Wages: An Essay in Statistical Economics New York, Augustus M. Kelley 1911.

Mincer, Jacob. Schooling, Experience, and Earnings New York: NBER 1974.

Oi, Walter Y.. "The Fixed Employment Costs of Specialized Labor." In The Measurement of Labor Costs, edited by Jack E. Triplett. Chicago: University of Chicago Press (for NBER), 1983. . "Employment Relations in Dual Labor Markets (“It's Nice Work If You Can Get It")." Journal of Labor Economics 8 (January 1990): S124-S149.

Rosen, Sherwin. "The Theory of Equalizing Differences." in Handbook of Labor Economics. edited by Orley C. Ashenfelter and Richard Layard. New York: North Holland, 1986.

Sattinger, Michael. "Assignment Models of the Distribution of Earnings." Journal of Economic Literature. XXXI (June 1983): 831-880.

Troske, Kenneth. "The Worker Establishment Characteristics Database." mimeo Washington D.C. : The Center for Economic Studies-U.S. Census Bureau (July 1993).

. The Growth and Survival of Firms and Changes in the Firm Size Distribution in Industries Ph.D. dissertation The University of Chicago, 1992.

U.S. Bureau of the Census. Alphabetical Index of Industries and Occupations Washington D.C.: U.S. Government Printing Office, 1992. 